\title{
Classification of Some Iraqi Soils Using Discriminant Analysis
}

\author{
Ahmad S. Muhameed and Amal M. Saleh \\ Dept. of Soil Sci. and Water Res. Agric. College - Univ. of Baghdad
}

\begin{abstract}
This study was carried out on some Iraqi soils in different regions of the country representating various physiographic units according to previous studies in soil survey and classification in order to classify them numerically using some physical, chemical, and mineral properties as variables in numerical classification. Sixteen sites were elected in the following areas:Mosul;Diyala;Baghdad;Babil;Wasit; and Najaf. Soil individuals were classified numerically using discriminant Analysis (Härdle and Simar, 2012) to check which variables that contribute statistically significant in predicting taxonomic levels that include each soil individual according to USDA system (Soil Survey Staff, 2010).

The results confirmed that the main variables that contributed to maximize accuracy in distinguishing taxonomic levels are as follows: content of sand of A horizon; content of clay of A horizon; Cation_exchange capacity $C E C$ of $A$, and $C$ horizons; content of calcium carbonate $\mathrm{CaCO}_{3}$ of $\mathrm{A}$ horizon; content of Opaque minerals of $C$ horizon; content of Amphiboles minerals of $A$, and $C$ horizons; content of Pyroxene minerals of $A$ horizon; content of Quartz mineral of $A$, and $C$ horizons; and content of Feldspar minerals of $A$, and $C$ horizons. Soil individuals were classified to five of taxonomic levels, these are: three soil individuals of Mosul were classified at subgroup level asTypic Calciargids, while the fourth soil individual of Mosul was classified at subgroup level as Typic Haplogypsids. Soil individuals of Diyala, Baghdad, and Babil were classified at subgroup level as TypicTorrifluvents, also one of the two soil individuals of Wasit was classified at subgroup level as TypicTorrifluvents, the other soil individual was classified at subgroup level as Typic Gypsiargids. Finally soil individual of Najaf was classified at subgroup level as Typic Calcigypsids, , which confirms the agreement of the results of discriminant Analysis with those of USDA system.
\end{abstract}

\section{Introduction}

Discriminant Function Analysis (DA) undertakes the same task as multiple linear regression by predicting an outcome. However, multiple linear regression is limited to cases where the dependent variable on the $\mathrm{Y}$ axis is an interval variable so that the combination of predictors will, through the regression equation, produce estimated mean population numerical $\mathrm{Y}$ values for given values of weighted combinations of $\mathrm{X}$ values.Discriminant analysis is a technique used to build a predictive model of group membership based on observed characteristics of each case (Agresti, 1996).

Mclachlan (2004) summarized the major underlying assumptions of DA as follows:

- the observations are a random sample;

- each predictor variable is normally distributed;

- each of the allocations for the dependent categories in the initial classification are correctly classified;

- there must be at least two groups or categories, with each case belonging to only one group so that the groups are mutually exclusive and collectively exhaustive (all cases can be placed in a group);

- each group or category must be well defined, clearly differentiated from any other group(s) and natural.

- the groups or categories should be defined before collecting the data;

- the attribute(s) used to separate the groups should discriminante quite clearly between the groups so that group or category overlap is clearly non-existent or minimal.

The degree of overlap between the discriminant score distributions can then be used as a measure of the success of the technique (Huberty and Olejnik, 2006).

\section{Types of Discriminant Analysis}

There are basically three types of DA: direct, hierarchical and stepwise. In direct DA, all the variables enter at once; in hierarchical DA, the order of variable entry is determine by the researcher; and instepwise DA, statistical criteria alone determine the order of entry (Afifi et al., 2011).

Stepwise discriminant analysis was used on particle size and heavy mineral data from 276 sediment samples, including 39 from published sources, to distinguish between Palaeocene and Plio-Pleistocene deposits, found above the Cretaceous Chalk in southeast England, and to determine parent materials of the soils and 
superficialdeposits of the central NorthDowns. Of 71 known cases (in situ deposits), $85.9 \%$ were correctly classified using textural data (sig. 99.9\%), and $89.7 \%$ of 29 known cases (sig. 99.9\%), using heavy mineral data. The best textural discriminanting variables were \%sand, graphic mean, \%clay and graphic skewness, and the best heavy mineral discriminants were \%kyanite plus staurolite, \%andalusite and \%garnet.

Carroll et al. (2006) discussed the outcomes of a research study undertaken through the use of undisturbed soil columns, to assess the ability different soil types to treat and dispose of primary treated effluent. Discriminant Analysis (DA) was utilised for classification of the various soil types based on their respective physical and chemical characteristics and to identify relative changes in each soil type after an extended period of application of effluent.Ferrosol and Dermosol soils were found to provide the most satisfactory conditions for effluent renovation.Kurosol,Sodosl, and Chromosolsoils even though were found to provide suitable means for removing effluent pollutants, reductions in the soils, permeability over time indicated that these soils may not be appropriate for long term effluent treatment.Finally,Podosol soils were found to have minimal ability to provide adequate treatment of effluent.

This study aims to classify soils representating various physiographic units numerically using instepwise DA and to identify the contribution of physical and chemical and mineral properties which were used in this analysis to increase the accuracy in distinguishing taxonomic levels (subgroup) according to soil taxonomy (Soil Survey Staff, 2010).

\section{Materials And Methods}

Sixteen sites were elected in different regions of Iraq according to previous studies in soil survey and classification which was performed by soil investigation department / Ministry of Irrigation, as follows: soil pedons 1, 2,3,4/Mosul; 5, 6,7 /Diyala; 8, 9,10 /Baghdad; 11, 12, 13 /Babil; 14, 15/Wasit; 16/Najaf as shown in fig. 1. Table 1 shows sites and classification of soil pedons according to USDA system.

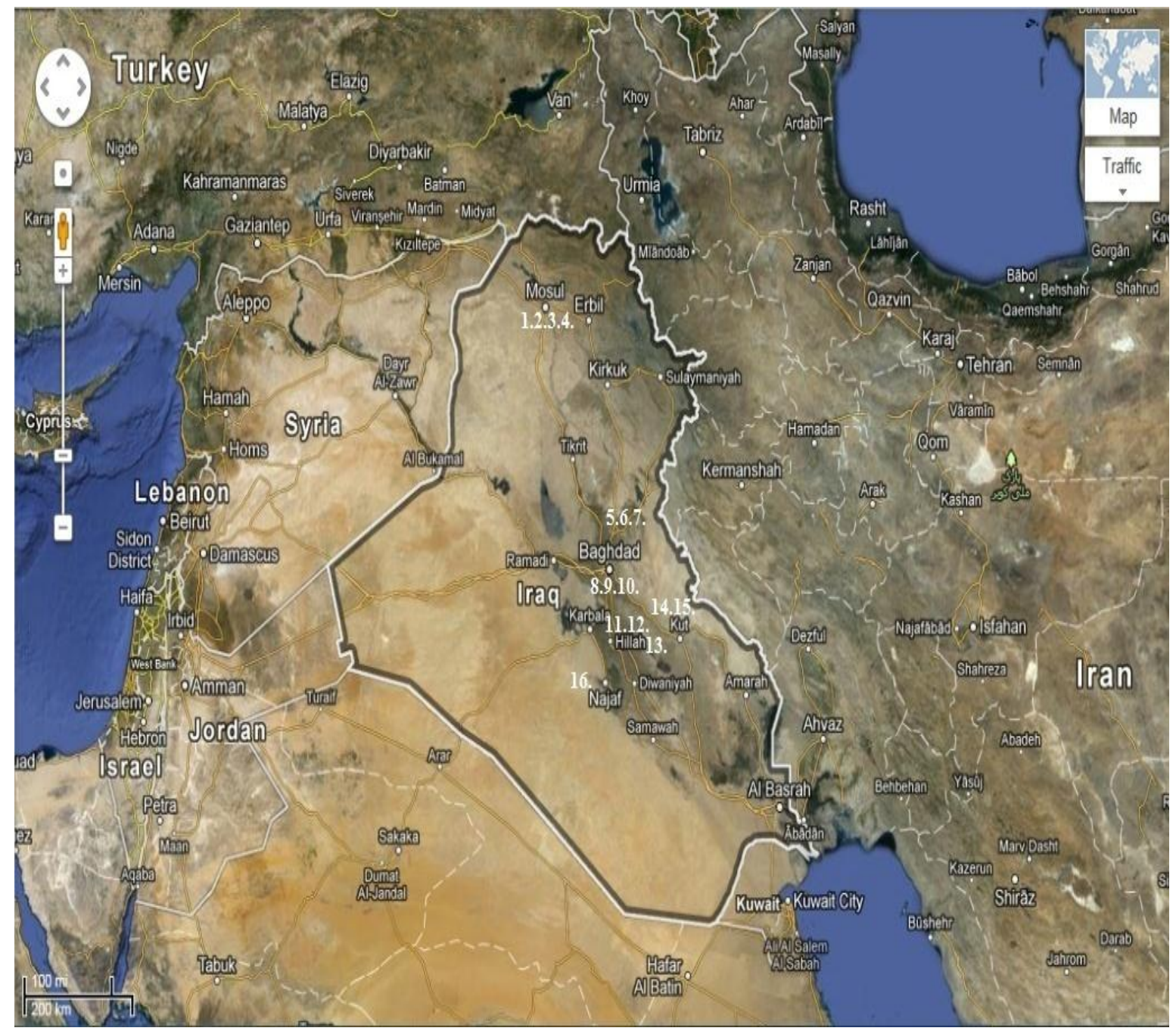

Fig. 1. Distribution of soil pedons sites within areas under study. 
Table 1. Classificationof soil pedons according to (Soil Survey Staff, 2010).

\begin{tabular}{|c|c|c|c|}
\hline Pedon No. & Order & Class of lower category & Location \\
\hline 1. & Aridisols & Typic Calciargids & Mosul \\
\hline 2. & Aridisols & Typic Haplogypsids & Mosul \\
\hline 3. & Aridisols & Typic Calciargids & Mosul \\
\hline 4. & Aridisols & Typic Calciargids & Mosul \\
\hline 5. & Entisols & Typic Torrifluvents & Diyala \\
\hline 6. & Entisols & Typic Torrifluvents & Diyala \\
\hline 7. & Entisols & Typic Torrifluvents & Diyala \\
\hline 8. & Entisols & Typic Torrifluvents & Baghdad \\
\hline 9. & Entisols & Typic Torrifluvents & Baghdad \\
\hline 10. & Entisols & Vertic Torrifluvents & Baghdad \\
\hline 11. & Entisols & Typic Torrifluvents & Babil \\
\hline 12. & Entisols & Typic Torrifluvents & Babil \\
\hline 13. & Entisols & Typic Torrifluvents & Babil \\
\hline 14. & Aridisols & Typic Gypsiargids & Wasit \\
\hline 15. & Entisols & Typic Torrifluvents & Wasit \\
\hline 16. & Aridisols & Typic Calcigypsids & Najaf \\
\hline
\end{tabular}

\section{Soil Characteristics (Variables)}

Mclachlan (2004) stated that when the application of discriminant analysis is used to predict the categories to which it belong soil individuals, it should be subject to the following conditions:

1. Continuous variables are independent (strength of a linear relationship between variables equal to zero).

2. The variables used in the discriminant analysis are follow multi-normal distribution.

Forty soil characteristics physical,chemical and mineral characteristics were chosen in the discriminant analysis.

\section{Statistical Methods Used In The Stepwise Discriminant Analysis}

Standardization Of Variables

The original variables were calibrated in order to give it the standard values so that each variable range between $0-1$ according to the following equation, proposed by Nisbet et al. (2009):

$X_{\mathrm{i}}^{*}=$ new standardized value of the variable.

$$
X_{\mathrm{i}}^{*}=\left(X_{i}-X_{\min .}\right) /\left(X_{\max .}-X_{\min .}\right)
$$

$X_{i}=$ original value of the variable.

$X_{\min .}=$ minimum value of the variable.

$X_{\max }=$ maximum value of the variable.

\section{Wilks' Lambda}

Härdle and Simar (2012) confirmed that Wilks lambda is ;

$$
\Lambda=\frac{S S_{\text {within_groups }}}{S S_{\text {total }}}
$$

So the smaller the $\Lambda$ the more doubt cast upon that null hypothesis. Determination how much of the variance in the grouping variable is explained by predictor variables by subtracting the $\Lambda$ from one.

\section{F Test}

Härdle and Simar (2012) explained that it is possible to specify F-to-Enter and F-to-Remove limits. Enter \#1 and Remove \#1 are used during forward stepping to control the entry or removal of variables. Enter and Remove \#2 are used for backward stepping. Entering variables must have Fs greater than the Enter limit. (For removal, Fs less than the Remove limit.) Remove must be less than Enter. Default: Enter $=3.84$; Remove $=2.71$.

\section{Discriminant Analysis Linear Equation}

DA involves the determination of a linear equation like regression that will predict which group the case belongs to. The form of the equation or function is:

$$
D=v_{1} X_{1}+v_{2} X_{2}+v_{3} X_{3}+\cdots v_{i} X_{i}+a
$$


$D=$ discriminante function

$v=$ the discriminant coefficient or weight for that variable

$X=$ respondent's score for that variable

$a=\mathrm{a}$ constant

$i=$ the number of predictor variables

This function is similar to a regression equation or function. The v's are unstandardized discriminant coefficients analogous to the b's in the regression equation. These v's maximize the distance between the means of the criterion (dependent) variable. Standardized discriminant coefficients can also be used like beta weight in regression. Good predictors tend to have large weights. this function maximize the distance between the categories, i.e. come up with an equation that has strong discriminantory power between groups. After using an existing set of data to calculate the discriminant function and classify cases, any new cases can then be classified. The number of discriminant functions is one less the number of groups. There is only one function for the basic two group discriminant analysis.

\section{Results And Discussion}

Soil individuals were classified according to soil taxonomy (Soil Survey Staff, 2010) and placed in the two taxonomic levels of orders Aridisols and Entisols and to five taxonomic levels of subgroup as follows: Typic Calciargids, Typic Haplogypsids, Typic Torrifluvents, Typic Gypsiargids, and Typic Calcigypsids (Table 1).

\section{Discriminanting Variables}

The adoption of discriminant analysis to predict taxonomic levels (subgroup), makes it possible to identify the variables that make asignificant contribution to predict those taxonomic levels which belong to each soil individual using $\mathrm{F}$ test. Table 2 shows whether there is a statistically significant differences between the means of the independent variables in the five taxonomic levels for the dependent variable.

It is clear that the independent variables that contributed to maximize accuracy in the five distinguishing taxonomic levels to which it belongs soil individualsare as follows: content of sand of $\mathrm{A}$ and $\mathrm{C}$ horizons; content of silt of $\mathrm{C}$ horizon; content of clay of $\mathrm{A}$ horizon; bulk density of $\mathrm{A}$ and $\mathrm{C}$ horizons; cation exchange capacity $\mathrm{CEC}$ of $\mathrm{A}$ and $\mathrm{C}$ horizons; content of organic matter of $\mathrm{A}$ horizon; content of calcium carbonate $\mathrm{CaCO} 3$ of $\mathrm{A}$ and $\mathrm{C}$ horizons; content of Opaque minerals of $\mathrm{A}$ and $\mathrm{C}$ horizons; content of Amphiboles minerals of $\mathrm{A}$ and $\mathrm{C}$ horizons; content of Garnet minerals of A and C horizons; content of Staurolite mineral of C horizon; content of Zircon mineral of A and C horizons; content of Quartz mineral of $\mathrm{C}$ horizon; content of Mica minerals of $\mathrm{A}$ horizon; and content of Chert mineral of $\mathrm{C}$ horizon.

The value of statistics Wilks ' Lambda is reflecting the low values of variation around the means of categories, so it is likely that the low value of $\Lambda$ statistically significant (Huberty and Olejnik, 2006).

Table 3 shows a summary of the steps through the system from entering the independent variables to the analysis and exclusion, as well as the value of $\Lambda$ Wilks ' Lambda and p-value associated with each case, the table also shows values of $F$ test function, the critical values of this function areranged from $(2.71-3.84)$ in order to input or delete variables to the analysis. 
Table 2.Analysis of variance for each independent variable ANOVAs Univariate

\begin{tabular}{|c|c|c|c|c|c|}
\hline Variable & Wilks' Lambda & $\mathbf{F}$ & df1 & df2 & Sig. \\
\hline Content of sand in A & .287 & 6.847 & 4 & 11 & .005 \\
\hline Content of sand in C & .180 & 12.564 & 4 & 11 & .000 \\
\hline Content of silt in A & .480 & 2.981 & 4 & 11 & .068 \\
\hline Content of silt in C & .227 & 9.350 & 4 & 11 & .002 \\
\hline Content of clay in A & .242 & 8.635 & 4 & 11 & .002 \\
\hline Content of clay in C & .502 & 2.727 & 4 & 11 & .085 \\
\hline Bulk density of $A$ & .123 & 19.539 & 4 & 11 & .000 \\
\hline Bulk density of C & .279 & 7.098 & 4 & 11 & .004 \\
\hline Cation _ exchange capacity of A & .270 & 7.441 & 4 & 11 & .004 \\
\hline Cation - exchange capacity of $\mathrm{C}$ & .240 & 8.691 & 4 & 11 & .002 \\
\hline Content of organic matter in A & .243 & 8.577 & 4 & 11 & .002 \\
\hline Content of organic matter in C & .475 & 3.044 & 4 & 11 & .065 \\
\hline Content of $\mathrm{CaCO}_{3}$ in $\mathrm{A}$ & .236 & 8.895 & 4 & 11 & .002 \\
\hline Content of $\mathrm{CaCO}_{3}$ in $\mathrm{C}$ & .276 & 7.223 & 4 & 11 & .004 \\
\hline EC of $A$ & .755 & .894 & 4 & 11 & .499 \\
\hline EC of $\mathrm{C}$ & .945 & .159 & 4 & 11 & .955 \\
\hline Content of Opaque minerals in A & .169 & 13.489 & 4 & 11 & .000 \\
\hline Content of Opaque minerals in C & .153 & 15.166 & 4 & 11 & .000 \\
\hline Content of Amphiboles in A & .247 & 8.389 & 4 & 11 & .002 \\
\hline Content of Amphiboles in C & .244 & 8.525 & 4 & 11 & .002 \\
\hline Content of Pyroxene in A & .470 & 3.097 & 4 & 11 & .062 \\
\hline Content of Pyroxene in C & .625 & 1.653 & 4 & 11 & .230 \\
\hline Content of Garnetin A & .207 & 10.529 & 4 & 11 & .001 \\
\hline Content of Garnetin C & .256 & 8.011 & 4 & 11 & .003 \\
\hline Content of Staurolite in A & .849 & .488 & 4 & 11 & .744 \\
\hline Content of Staurolite in C & .253 & 8.121 & 4 & 11 & .003 \\
\hline Content of Epidote in A & .457 & 3.269 & 4 & 11 & .054 \\
\hline Content of Epidote in C & .760 & .868 & 4 & 11 & .513 \\
\hline Content of Zircon in A &. .163 & 14.128 & 4 & 11 & .000 \\
\hline Content of Zircon in C & .020 & 133.990 & 4 & 11 & .000 \\
\hline Content of Quartzin A & .494 & 2.818 & 4 & 11 & .078 \\
\hline Content of QuartzinC & .372 & 4.637 & 4 & 11 & .019 \\
\hline Content of Feldsparin A & .662 & 1.403 & 4 & 11 & .296 \\
\hline Content of FeldsparinC & .909 & .275 & 4 & 11 & .888 \\
\hline Content of Mica in A & .215 & 10.037 & 4 & 11 & .001 \\
\hline Content of Mica inC & .539 & 2.355 & 4 & 11 & .118 \\
\hline Content of Chert in A & .588 & 1.926 & 4 & 11 & .176 \\
\hline Content of Chert in C &. $\mathbf{3 3 1}$ & 5.556 & 4 & 11 & .011 \\
\hline Content of Chlorite in A & .634 & 1.590 & 4 & 11 & .245 \\
\hline Content of Chlorite in C & .831 & .559 & 4 & 11 & .697 \\
\hline
\end{tabular}

Table 3. Entry and the exclusion steps of the discriminanting variables.

\begin{tabular}{|c|c|c|c|c|c|c|c|c|c|c|c|c|c|}
\hline \multicolumn{14}{|c|}{ Variables Entered/Removed ${ }^{a, b, c}$} \\
\hline \multirow{3}{*}{ के } & \multirow{3}{*}{ 预 } & \multicolumn{12}{|c|}{ Wilks' Lambda } \\
\hline & & \multirow{2}{*}{$\begin{array}{c}\text { Statisti } \\
\text { c }\end{array}$} & \multirow[t]{2}{*}{$\begin{array}{l}\text { df1 } \\
\end{array}$} & \multirow[t]{2}{*}{ df2 } & \multirow[t]{2}{*}{ df3 } & \multicolumn{4}{|c|}{$\overline{\text { Exact } \mathrm{F}}$} & \multicolumn{4}{|c|}{ Approximate $\mathbf{F}$} \\
\hline & & & & & & Statistic & df1 & df 2 & Sig. & Statistic & df1 & df 2 & Sig. \\
\hline 1 & $\begin{array}{l}\text { Content } \\
\text { of Zircon } \\
\text { in C }\end{array}$ & .020 & 1 & 4 & 11.000 & 133.990 & 4 & 11.000 & .000 & & & & \\
\hline 2 & $\begin{array}{l}\text { Bulk } \\
\text { density of } \\
\text { A }\end{array}$ & .002 & 2 & 4 & 11.000 & 49.778 & 8 & 20.000 & .000 & & & & \\
\hline 3 & $\begin{array}{l}\text { Content } \\
\text { of } \mathrm{CaCO}_{3} \\
\text { in } \mathrm{C}\end{array}$ & .000 & 3 & 4 & 11.000 & & & & & 37.353 & 12 & 24.103 & .000 \\
\hline 4 & $\begin{array}{l}\text { Content } \\
\text { of } \\
\text { Opaque } \\
\text { in A }\end{array}$ & .000 & 4 & 4 & 11.000 & & & & & 39.145 & 16 & 25.078 & .000 \\
\hline 5 & $\begin{array}{l}\text { Content } \\
\text { of } \\
\text { Garnet in } \\
\text { A }\end{array}$ & .000 & 5 & 4 & 11.000 & & & & & 40.452 & 20 & 24.166 & .000 \\
\hline
\end{tabular}


Classification Of Some Iraqi Soils Using Discriminant Analysis

\begin{tabular}{|c|c|c|c|c|c|c|c|c|c|}
\hline 6 & $\begin{array}{l}\text { organic } \\
\text { matter in } \\
\text { A }\end{array}$ & .000 & 6 & 4 & 11.000 & 47.351 & 24 & 22.142 & .000 \\
\hline 7 & $\begin{array}{l}\text { Content } \\
\text { of } \\
\text { Pyroxene } \\
\text { in C }\end{array}$ & .000 & 7 & 4 & 11.000 & 60.361 & 28 & 19.450 & .000 \\
\hline
\end{tabular}

At each step, the variable that minimizes the overall Wilks' Lambda is entered.

a. Maximum number of steps is $\mathbf{8 0}$.

b. Minimum partial $F$ to enter is 3.84 .

c. Maximum partial $\mathbf{F}$ to remove is 2.71 .

Table 4 lists pooled within-groups correlations between discriminanting variables and standardized canonical discriminant functions.Variables ordered by absolute size of correlation within function. The first discriminantion function based on the content of Chert mineral of $\mathrm{A}$ and $\mathrm{C}$ horizons; cation exchange capacity CEC of A and C horizons; content of Garnet minerals of $\mathrm{C}$ horizon; content of Amphiboles minerals of $\mathrm{A}$ and $\mathrm{C}$ horizons; and bulk density of $\mathrm{C}$ horizon.

It turns out that the second discriminantion function based on the content of Zircon mineral of $\mathrm{C}$ horizon;Electrolytic conductivity EC of A and C horizons; clay content of C horizon;content of Mica minerals of A horizon;content of sand of $\mathrm{C}$ horizon;content of Staurolite mineral of $\mathrm{C}$ horizon;content of calcium carbonate $\mathrm{CaCO}_{3}$ of $\mathrm{A}$ and $\mathrm{C}$ horizons; and silt content of $\mathrm{A}$ horizon.

The third discriminant function based on the content of Chlorite minerals of $\mathrm{A}$ and $\mathrm{C}$ horizons; content of Opaque minerals of A horizon; sand content of A horizon; clay content of A horizon; and content of Quartz mineral of A horizon. It was also noted that the fourth discriminant function based on the content of Quartz mineral of $\mathrm{C}$ horizon; content of organic matter of $\mathrm{A}$ and $\mathrm{C}$ horizons; content of Mica minerals of $\mathrm{C}$ horizon; bulk density of A horizon; content of Feldspar minerals of $\mathrm{A}$ and $\mathrm{C}$ horizons; content of Pyroxene minerals of $\mathrm{A}$ and $\mathrm{C}$ horizons; silt content of $\mathrm{C}$ horizon; content of Staurolite mineral of A horizon; content of Epidote mineral of $\mathrm{A}$ and $\mathrm{C}$ horizons; content of Garnet minerals of A horizon; content of Opaque minerals of $\mathrm{C}$ horizon; and content of Zircon mineral of A horizon.

The mark*in Table 4 indicates the high values of correlation coefficients of these variables.

Table 4. Correlation coefficients between discriminanting variables and discriminant functions.

\begin{tabular}{|c|c|c|c|c|}
\hline \multirow{2}{*}{ Variable } & \multicolumn{4}{|c|}{ Function } \\
\hline & 1 & 2 & 3 & 4 \\
\hline "Content of Chert in $\mathrm{C}$ & $-.709^{*}$ & (130 & .430 & (120 \\
\hline Cation _ exchange capacity of $\mathbf{A}$ & -.538 & -.186 & .232 & -.371 \\
\hline Content of Garnetin C & .486 & .036 & .131 & -.125 \\
\hline Cation _ exchange capacity of $\mathrm{C}$ & $-.479^{*}$ & .337 & .021 & -.012 \\
\hline Content of Amphiboles in C & $-.390^{*}$ & -.095 & .097 & .220 \\
\hline Content of Chert in A & $-.341^{*}$ & -.212 & -.099 & .104 \\
\hline Bulk density of $\mathbf{C}$ & $-.219^{*}$ & .044 & -.132 & .035 \\
\hline Content of Amphiboles in A & $-.218^{*}$ & -.184 & .107 & .006 \\
\hline Content of Zircon in $C^{a}$ & .037 & $.905^{*}$ & -.007 & -.224 \\
\hline EC of C & .250 & $.584^{*}$ & -.067 & .149 \\
\hline Content of clay in C & -.095 & $.559^{*}$ & -.227 & .210 \\
\hline EC of $A$ & .435 & $.524^{*}$ & -.185 & .304 \\
\hline Content of Mica in A & .146 & $.432^{*}$ & -.053 & -.256 \\
\hline Content of sand in C & .307 & $-.362^{*}$ & .280 & .056 \\
\hline Content of Staurolite in C & .160 & $.353^{*}$ & -.334 & -.345 \\
\hline Content of $\mathrm{CaCO}_{3}$ in $\mathrm{A}$ & .058 & -.238 & -.010 & .057 \\
\hline Content of silt in A & -.058 & $.232^{*}$ & -.172 & -.201 \\
\hline Content of $\mathrm{CaCO}_{3}$ inC $^{\mathrm{a}}$ & -.040 & .113 & .011 & .058 \\
\hline Content of Chlorite in A & -.033 & .022 & $.469^{\circ}$ & -.269 \\
\hline Content of Chlorite in C & -.113 & -.338 & $.447^{*}$ & .207 \\
\hline Content of Opaque minerals in $\mathrm{A}^{\mathrm{a}}$ & .022 & .110 & $-.308^{*}$ & .161 \\
\hline Content of sand in $A$ & .163 & -.180 & $.255^{\circ}$ & .073 \\
\hline Content of clay in $\mathrm{A}$ & -.215 & .011 & $-.227^{*}$ & .138 \\
\hline Content of Quartz in A & .041 & -.073 & $.211^{*}$ & -.066 \\
\hline Content of Quartz in C & .021 & -.007 & .114 & $-.723 *$ \\
\hline Content of organic matter in $\mathbf{A}^{\mathrm{a}}$ & .026 & -.119 & -.042 & $.709^{*}$ \\
\hline Content of Mica in C & .220 & -.226 & .093 & $.560^{*}$ \\
\hline Bulk density of $A^{a}$ & .021 & .087 & .387 & $-.431^{*}$ \\
\hline Content of Feldspar in C & .167 & .083 & -.191 & $-.415^{*}$ \\
\hline Content of Pyroxene in A & .243 & .104 & .131 & $.399^{*}$ \\
\hline Content of silt in C & -.329 & -.210 & -.113 & $-.362^{*}$ \\
\hline Content of Staurolite in A & .107 & .130 & .167 & $-.354^{*}$ \\
\hline
\end{tabular}


Classification Of Some Iraqi Soils Using Discriminant Analysis

\begin{tabular}{|l|l|l|l|l|}
\hline Content of organic matter in C & -.051 & .109 & .133 & $-.293^{*}$ \\
\hline Content of Epidote in C & .202 & .023 & -.044 & $.272^{*}$ \\
\hline Content of Feldsparin A & -.192 & .111 & -.150 & $-.268^{*}$ \\
\hline Content of Garnetin $\mathrm{A}^{\mathrm{a}}$ & .032 & .075 & -.240 & $-.241^{*}$ \\
\hline Content of Opaque minerals in C & -.039 & -.091 & .146 & $.234^{*}$ \\
\hline Content of Epidote in A & .22 & .058 & -.011 & $.221^{*}$ \\
\hline Content of Zircon in A & -.111 & -.093 & .112 & $.128^{*}$ \\
\hline Content of Pyroxene in $\mathrm{C}^{\mathrm{a}}$ & .019 & .007 & .063 & $.092^{*}$ \\
\hline
\end{tabular}

*. Largest absolute correlation between each variable and any discriminant function.

a. This variable used in the analysis.

\section{Numerical Classes}

\section{First Class $\mathbf{C}_{1}$}

This class has soil individuals of $1,3,4$, as shown in Table 5, there was a similarity in some physical properties used in discriminant analysis such as silt content of A horizon with $415.60 \mathrm{~g} \mathrm{~kg}^{-1}, 452.50 \mathrm{~g} \mathrm{~kg}^{-1}$, $399.60 \mathrm{~g} \mathrm{~kg}^{-1}$ of these soil individuals respectively, while the bulk density values of A horizon were $1.35 \mathrm{Mg} \mathrm{m}^{-3}$, $1.33 \mathrm{Mg} \mathrm{m}^{-3}, 1.33 \mathrm{Mg} \mathrm{m}^{-3}$ of $1,3,4$ soil individuals respectively.

When comparing chemical properties, there was a similarity in the cation exchange capacity CEC of A horizon with $15.63 \mathrm{Cmol}_{\mathrm{C}} \mathrm{kg}^{-1}, 14.90 \mathrm{Cmolc} \mathrm{kg}^{-1}, 11.97 \mathrm{Cmol}_{\mathrm{C}} \mathrm{kg}^{-1}$ of $1,3,4$ soil individuals respectively, while the values of the content of organic matter for this horizon were $15.92 \mathrm{~g} \mathrm{~kg}^{-1}, 18.03 \mathrm{~g} \mathrm{~kg}^{-1}, 19.21 \mathrm{~g} \mathrm{~kg}^{-1}$ of those soil individuals respectively.

Also there was a similarity of values of the content of heavy minerals of soil individuals in this class, the values of the content of Opaque minerals of A horizon were $62.86 \%, 62.65 \%, 72.38 \%$ of 1, 3, 4 soil individuals respectively, while the values of the content of Epidote mineral of $\mathrm{C}$ horizon were $6.89 \%, 5.15 \%, 5.18 \%$ of these soil individuals respectively.

There was a similarity of values of the content of light minerals of soil individuals, the values of the content of Quartz mineral of C horizon were $30.83 \%, 32.52 \%, 24.10 \%$ of 1, 3, 4 soil individuals respectively, while the values of the content of Feldspar minerals of A horizon were $9.00 \%, 10.29 \%, 10.59 \%$ of those soil individuals respectively.

The results indicated that there was a harmony in the discriminant analysis results with USDA system, the soil individuals were classified at subgroup level asTypic Calciargids.

\section{Second Class $\mathbf{C}_{2}$}

This class has a soil individual 2 (Table 5). When comparing physical properties, it was noted that the value of the content of sand for A horizon was $591.50 \mathrm{~g} \mathrm{~kg}^{-1}$, while the value of clay content of this horizon was $158.10 \mathrm{~g} \mathrm{~kg}^{-1}$ of 2 soil individual.

The value of cation exchange capacity CEC of A horizon was $10.30 \mathrm{Cmolc} \mathrm{kg}^{-1}$, while the value of the organic matter content for this horizon was $8.14 \mathrm{~g} \mathrm{~kg}^{-1}$ of 2 soil individual.

Table 5. Final results of the classification of soil individuals understudy.

\begin{tabular}{|c|c|c|c|c|c|c|c|}
\hline \multicolumn{8}{|c|}{ Classification Results $^{\mathrm{a}}$} \\
\hline & \multirow[b]{2}{*}{ Class } & \multicolumn{5}{|c|}{ Predicted Group Membership } & \multirow[b]{2}{*}{ Total } \\
\hline & & $\begin{array}{c}\text { Typic } \\
\text { Calciargids }\end{array}$ & $\begin{array}{c}\text { Typic } \\
\text { Haplogypsids }\end{array}$ & $\begin{array}{c}\text { Typic } \\
\text { Torrifluvents }\end{array}$ & $\begin{array}{c}\text { Typic } \\
\text { Gypsiargids }\end{array}$ & $\begin{array}{c}\text { Typic } \\
\text { Calcigypsids }\end{array}$ & \\
\hline \multirow[t]{10}{*}{$\begin{array}{l}\text { Original } \\
\text { Count }\end{array}$} & \multirow{5}{*}{$\begin{array}{l}\text { Typic } \\
\text { Calciargids } \\
\text { Typic } \\
\text { Haplogypsids } \\
\text { Typic } \\
\text { Torrifluvents } \\
\text { Typic } \\
\text { Gypsiargids } \\
\text { Typic } \\
\text { Calcigypsids }\end{array}$} & 3 & $\mathbf{0}$ & $\mathbf{0}$ & $\mathbf{0}$ & $\mathbf{0}$ & 3 \\
\hline & & $\mathbf{0}$ & 1 & $\mathbf{0}$ & $\mathbf{0}$ & $\mathbf{0}$ & 1 \\
\hline & & $\mathbf{0}$ & $\mathbf{0}$ & 10 & $\mathbf{0}$ & $\mathbf{0}$ & 10 \\
\hline & & $\mathbf{0}$ & $\mathbf{0}$ & $\mathbf{0}$ & 1 & $\mathbf{0}$ & 1 \\
\hline & & $\mathbf{0}$ & $\mathbf{0}$ & $\mathbf{0}$ & $\mathbf{0}$ & 1 & 1 \\
\hline & \multirow{5}{*}{$\begin{array}{l}\text { Typic } \\
\text { Calciargids } \\
\text { Typic } \\
\text { Haplogypsids } \\
\text { Typic } \\
\text { Torrifluvents } \\
\text { Typic } \\
\text { Gypsiargids } \\
\text { Typic } \\
\text { Calcigypsids }\end{array}$} & 100.0 & .0 & .0 & .0 & .0 & 100.0 \\
\hline & & .0 & 100.0 & .0 & .0 & .0 & 100.0 \\
\hline & & .0 & .0 & 100.0 & .0 & .0 & 100.0 \\
\hline & & .0 & .0 & .0 & 100.0 & .0 & 100.0 \\
\hline & & .0 & .0 & .0 & .0 & 100.0 & 100.0 \\
\hline
\end{tabular}


When comparing the content of heavy and light minerals, , it was noted that the value of the content of Opaque minerals of A horizon was $51.85 \%$ for this soil individual, while the value of the content of Garnet minerals for this horizon was $15.33 \%$ of 2 soil individual. The value of the content of Quartz mineral of $\mathrm{C}$ horizon was $33.33 \%$, while the content of Chert mineral of A horizon was $15.71 \%$.

The results of the discriminant analysis confirmed that the soil individual 2 was classified at subgroup level as Typic Haplogypsids according to USDA system.

\section{Third Class $\mathrm{C}_{3}$}

This class has soil individuals of 5, 6, 7, 8, 9, 10,11, 12, 13, 15 (Table 5), when comparing physical properties used in the discriminant analysis, it was noted that the value of silt content of $\mathrm{C}$ horizon ranged between $\left(392.60 \mathrm{~g} \mathrm{~kg}^{-1}-569.90 \mathrm{~g} \mathrm{~kg}^{-1}\right)$ of these soil individuals, while the value of clay content of A horizon ranged between $\left(275.20 \mathrm{~g} \mathrm{~kg}^{-1}-451.40 \mathrm{~g} \mathrm{~kg}^{-1}\right)$ for soil individuals in this class.

When comparing the chemical properties of soil individuals, it was noted that the value of cation exchange capacity CEC of A horizon ranged between $\left(12.40 \mathrm{Cmolc} \mathrm{kg}-1-27.60 \mathrm{Cmolc} \mathrm{kg}^{-1}\right)$, while the value of content of calcium carbonate $\mathrm{CaCO}_{3}$ of $\mathrm{C}$ horizon ranged between $\left(262.90 \mathrm{~g} \mathrm{~kg}^{-1}-478.65 \mathrm{~g} \mathrm{~kg}^{-1}\right)$ of those soil individuals.

When comparing the content of heavy and light minerals, it was noted that the value of content of Opaque minerals of A horizon ranged between $(13.87 \%-52.75 \%)$ of the soil individuals in this class, while the value of content of Amphiboles minerals of $\mathrm{C}$ horizon ranged between (12.16\%-51.53\%). The value of content of Quartz mineral of A horizon ranged between (21.62\%-41.58\%), while the value of content of Mica minerals of $\mathrm{C}$ horizon ranged between $(7.59 \%-23.19 \%)$ of soil individuals of this class.

The comparison of the discriminant analysis with USDA system indicated that the soil individuals of this class were Compatible at subgroup level as Typic Torrifluvents.

\section{Fourth Class $\mathbf{C}_{4}$}

This class has a soil individual 14 (Table 5).When comparing physical, chemical, and mineral properties used in the discriminant analysis, it was noted that the value of the content of sand for A horizon was $487.80 \mathrm{~g} \mathrm{~kg}^{-1}$, while the value of clay content of $\mathrm{C}$ horizon was $196.30 \mathrm{~g} \mathrm{~kg}^{-1}$ for this soil individual.

The value of cation exchange capacity CEC of A horizon was $7.41 \mathrm{Cmolc} \mathrm{kg}^{-1}$, while the value of the content of calcium carbonate $\mathrm{CaCO}_{3}$ for $\mathrm{C}$ horizon was $514.55 \mathrm{~g} \mathrm{~kg}^{-1}$ of 14 soil individual.

When comparing the content of heavy and light minerals, it was noted that the value of the content of Opaque minerals of A horizon was $63.97 \%$ for this soil individual, while the value of the content of Garnet minerals for C horizon was $9.94 \%$ of 14 soil individual. The value of the content of Quartz mineral of C horizon was $30.34 \%$, while the value of the content of Chert mineral of A horizon was $17.11 \%$ of 14 soil individual.

The results of the discriminant analysis confirmed that the soil individual 14 was classified at subgroup level as Typic Gypsiargids according to USDA system.

\section{Fifth Class $\mathbf{C}_{5}$}

This class has a soil individual 16 (Table 5).When comparing physical, chemical, and mineral properties used in the discriminant analysis, it was noted that the value of the content of sand for $\mathrm{C}$ horizon was $954.00 \mathrm{~g} \mathrm{~kg}^{-1}$, while the value of clay content of A horizon was $148.00 \mathrm{~g} \mathrm{~kg}^{-1}$ for this soil individual.

The value of cation exchange capacity CEC of A horizon was $7.04 \mathrm{Cmolc} \mathrm{kg}^{-1}$, while the value of the content of calcium carbonate $\mathrm{CaCO}_{3}$ for this horizon was $493.60 \mathrm{~g} \mathrm{~kg}^{-1}$ of 16 soil individual.

When comparing the content of heavy and light minerals, it was noted that the value of the content of Opaque minerals of A horizon was $45.59 \%$ for this soil individual, while the value of the content of Zircon mineral for C horizon was $16.96 \%$ of 16 soil individual.The value of the content of Quartz mineral of C horizon was 31.94\%, while the value of the content of Mica minerals of A horizon was $11.84 \%$ of 16 soil individual.

The results of the discriminant analysis confirmed that the soil individual 16 was classified at subgroup level as Typic Calcigypsids according to USDA system.

\section{Conclusions}

The results of the study indicate a harmony of numerical classes of discriminant analysis with the USDA classification system at subgroup level.This fact confirms that the physical, chemical, and mineral properties used as variables in this analysis contributed statistically significant to predict taxonomic levels.

\section{References}


[1]. Afifi, A.; S. May; and V.A. Clark. 2011. Practical multivariate analysis. Fifth edition (Chapman \& Hall/CRC Texts in Statistical Science).

[2]. Agresti, A. 1996. An introduction to categorical data analysis. John Wiley and Sons.

[3]. Bryman, A.; and D. Cramer. 2001. Quantitative data analysis with SPSS release 10 for windows. First published by Routledge 27 Church Road, Hove, East Sussex BN3 2FA.

[4]. Carroll, S.;A. Goonetilleke; K. Wael Al-Shiekh; and R. Frost. (2006). Assessment via discriminant analysis of soil suitability for effluent renovation using undisturbed soil columns. Geoderma, 131: 201-217.

[5]. Härdle,W.K.; and L. Simar. 2012. Applied multivariate statistical analysis. Sixth edition. Copyrighted Material.

[6]. Huberty, C. J. 1994. Applied discriminant analysis. Second edition. Copyrighted Material.

[7]. Huberty, C. J.; and S. Olejnik. 2006. Applied MANOVA and Discriminant analysis. Wiley Series in Probability and Statistics.

[8]. Mclachlan, G. J. 2004. Discriminant analysis and statistical pattern recognition. Wiley Series in Probability and Statistics.

[9]. Nisbet, R; J. Elder; and G. Miner. 2009. Handbook of statistical analysis and data mining applications. Copyrighted Material.

[10]. Soil Survey Staff. 2010. Keys to soil taxonomy. 11 $1^{\text {th }}$.ed; USDA- Natural Resources Conservation Service.

[11]. Wilson, D. I. 2002.Derivation of the chalk superficial deposits of the North Downs, England: an application of discriminant analysis. Geomorphology, 42: 343-364. 